$$
\begin{aligned}
& \text { MSIL } \\
& \text { corrosion of steel Tendons in concrete } \\
& \text { pressure of Recent } \\
& \text { Literalure and Experimental investigations }
\end{aligned}
$$


NURËG/CR-0092

ORNL/NUREG-37

Dist. Category R5

Contract No. W-7405-eng-26

METALS AND CERAMICS DIVISIUN

CORROSION OF STEEL TENDONS IN CONCRETE PRESSURE VESSELS - REVIEW OF RECENT LITERATURE AND EXPERIMENTAL INVESTIGATIONS

J. C. Griess

Manuscript Completed - April 14, 1978

Date Published: June 1978

Prepared for the

U.S. Nuclear Regulatory Comission

Office of Nuclear Regulatory Research

Under Interagency Agreements DOE 40-551-75 and 40-552-75

NRC FIN No. BO11S

Prepared by the

OAK RIDGE IIATIONAL LABORATORY

operated by

UNION CARBIDE CORPORATION

for the

DEPARTMENT OF ENERGY

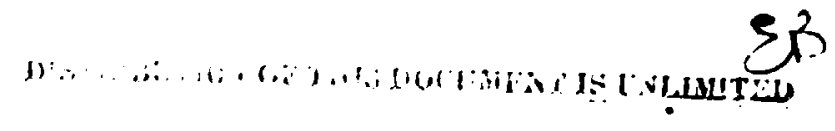


CONTENTS

ABSTRACT ............................ . 1

INTRODUCTION .......................... 1

LOCALIZED CORROSION . . . . . . . . . . . . . . . . 2

pitting ....................... 3

Crevice Corrosion .................. . . 4

Stress-Corrosion Cracking . . . . . . . . . . . . s

Hydrogen Embrittlement ................... 6

CORROSION OF CARBON STEEL . . . . . . . . . . . . . . . . 7

General Corrosion of Steel in Aqueous Environments . . . . . 8

Stress-Corrosion Cracking of Steel . . . . . . . . . . 9

Corrosion of Steel in Concrete and in

Organic Compounds ................. 12

EXPERIMENTAL INVESTIGATION . . . . . . . . . . . . . 17

Experimental Considerations ................ 17

Experimental Procedures ................. 18

Results ...................... 20

DISCUSSION . . . . . . . . . . . . . . . . . . 28

SUMARY ........................... 34

ACKNOWLEDGENTS . . . . . . . . . . . . . . . . . 35

REFERENCES . . . . . . . . . . . . . . . . . 35 
CORROSION OF STEEL TENDONS ON CONCRETE PRESSURE VESSELS - REVIEN

OF RECENT LITERATURE AND EXPERTEENTAL INVESTIGATIONS

J. C. Griess

\begin{abstract}
The fundarentals of localized corrosion are briefly discussed, and the literature concerning corrosion of carbon steel in aqueous enviroments, in particular the stresscorrosion cracking of carbon steels, is reviewed. The behavior of high-strength steels in specific enviroments, including concrete and organic substances, is also sumarized. The avallable Inforuation Indicates that the corrosion of steels in correctly formulated concrete is miuinal. Even appreciable concentrations of chloride, sulfate, sulfide, and nitrate salts can be tolerated in the coincrete or grout without detrimental effects. Adherence to established standards in the preparation and application of grouts in tendon-bearing conduits should guarantee very long tendon 1ifetimes. Little is reported about the behavior of tendons in proprletary organic greases or waxes, but very good corrosion resistance is expected if the organic material remains intact.

Stress-corrosion cracking tests performed with AISI 1080 steel tendon wires, using the constant-strain-rate method, produced results expected from data in the literature. Cracking was observed only in neutral or acid solutions containing hydrogen sulfide, in amonium nitrate solutions, and possibly In a dilute solution of sodium bisulfite. Ceneral corrosion tests in water and in dilute solutions of sodium nitrate, chloride, or sulfate showed that oxygen was an lmportant factor; corrosion was substantially greater when oxygen had free access to the solution than when access to oxygen was restricted. In the tests with oxyger. the heaviest attack on the steel tendons was at the waterline of the solution.
\end{abstract}

\title{
INTRODUCTION
}

In the construction of concrete pressure vessels, high-strength steel cendons are usually atrung through vertical conduits and stressed to some predetermined level. After tensioning, the conduits with the tendons in place are pumped full of either a concrete grout or an organic 
substance (petroleum-base grease or wax with additives) to provide corrosion protection to the tendons. Although steels are normally quite compatible with concrete and most organic compounds, the presence of impurities in either substance, which could be leached into pockers of water, could cause serious corrosion, eventually isading to fai...ure of the load-carrying tendons.

In a test with a small-scale model of a concrete pressure vessel conducted at Oak Ridge Nationa? Laboratory, sone of the cold-worked AISI 1080 steel (conforming to ASTM A 416, grade 270) tensioning tendons failed, and the failures appeared to be caused by stre:ss-corrosion. cracking. 1 The tendons were supposed to be protected iy a proprietary wax, but there was evidence that wax did not completily fill all of the conduits. In addition, some unusual conditions existed during the test which could have been responsible for the cracking. Although it was rot proven, ammonium nitrate in the environment was suggested as the cause of cracking.

As a result of the above experience and at the request of the Nuclear Regulatory Commisston, we conducted a review of recent literature on the cracking of high-strength steels and, subsequently, a 1 imited exper:mental program to determine the relative susceptibility of cold-worked AISI 1080 steel to cracking in several environments. This report presents the results. Before presenting the results from the literature review and test program, a few pertinent facts about localized corrosion are reviewed. Recognition of these facts is essential to an understanding of the 11 terature.

\section{LOCALIZED CORROSION}

For the purpose of this discussion, corrosion is defined as the destructive action of an environment on a metallic substance. In the process, the metal 18 oxidized and some component in the environment is reduced. That part of the process involving oxidation 18 called the anodic reaction, and the reduction part is called the cathodic reaction. In some forms of corrosion, visual examination of a corroded surface does not allow location of specific anodic and cathodic areas, but in other 
cases, anodic and cathodic areas are clearly separated. Since the overall corrosion process in aqueous environments involves the transfer of electrons and the formation of ions, corrosion is an electrochemical process and is subject to the lavs of electrochemical kinetics. While it is not the purpose of this paper to duell on the electrochemical nature of corrosion, one should not lose sight of this fact when discussing corrosion-related phenomena.

Corrosion can manifest itself in two general ways: uniform dicsolution or thinning, and localized attack. Although the former mode of attack occasionaliy produces fallures, by far the largest number of serious failures is produced by localized corrosion, which implies corrosion on only a small area of the metal exposed io the environment. Pitting, crevice corrosion, and stress-corzosion cracking (SCC) are probably the most common forms of localized attack, but others such as corrosion fatigue, grain-boundary attack, Impingement and erosive attack, and selective dissolution of one element from an alloy (e.g., dezincification of brass) also are capable of producing fallures. Although somewhat different in origin, hydrngen embrittlement is frequently classed as localized attack.

Most corrosion-related fallures are produced by either pitting, crevice corrosion, SCC, hydrogen embrittlemenc, or by combinations of them. In the following paragraphs, some pertinent facts about each of these types of attack are presented.

\section{Pitting}

When random penetrations which have depths equal to or greater than the diameter occur on freely exposed surfaces, the material is said to have undergone pitting. Pits are of ten nearly hemispherical and distinguished from cracks primarily by their shape and depth. Pitting is most likely to occur in an environment in which the metal is nearly inert (passfive) but where breakdown of passivity occurs in very small random areaz. Halide lons, particularly chloride lons, are notorfous for thefr ability to produce pitting. 
When pitting cecurs, the anodic current density on the walls of the pit is much greater than the current density on the surface surrounding the pit, although the total anodic and cathodic currents must be equal. As a pit deepens, aixing of the electrolyte in the pit with the bulk solution is limited, and the composition of the solution in the pit is signiftcantly different from that of the bulk solution. In most cases the $\mathrm{pH}$ of the soiution in the pit is lower than that of the bulk solution because of hydrolysis of the weta] Ions. Frequently, hydrolysis products precipitate at the wouth of the pit and further restrict $\mathrm{mixing}$ of the solution in the pit with the bulk solution. The acidity of the pit solution can be important in other forms of attack such as hydrogen embrittlement or SCC.

\section{Crevice Corrosion}

In many aspects, crevice corrosion is similar to pitting, but its origin is somewhat different. Crevice corrosion occurs when access of the bulk solution to parts of the metal surface is limited and in environments when the metals are passive in the absence of crevices. In such solutions, passivity usually depends on the presence of an oxidiztag agent, usually oxygen.

When such a metal with a crevice is first placed in an aerated solution, all surfaces ithose freely exposed as well as those in crevice regions) are exposed to the same solution. However, because of the minute quantity of cxygen in the volume of solution in the crevice, only a very small amount of corrosion is required to consume all of the oxygen. since mixing of the solution in the crevices with the bulk solution is very restricted, diffusion of oxygen into the crevice cannot keep up with the demand for it in the corrosion process. As a result, the anodic reaction within the crevice is maintained by cathodic reduction of oxygen on the surfaces outside of the crevice. To electrically balance the positive metal lons formed in the crevice, negatively charged lons, under influence of the potential field, migre:e Into the crevice. As with pitting, hydrolysis of the metal lons produces free acid in the crevice, and this leads to further acceleration of corrosion. Thus the 
initiation of pitting and crevice corrosion is different, but once established the mechanises that produce continued corrosion are essentially the same.

\section{Stress-Corrosion Cracking}

Stress-corrosion cracking is a form of fallure expertenced by alloys when subjected to a tensile stress during exposure to specific environwents. In most cases, pure metals are not subject to SCC, but there are exceptions. Usually there is an apparent stress level below which cracking w11 not occur; of ten this level is considerably below the yfeld stress as determined in air. Stress-corrosion cracks have the appearance of a brittle fallure in a ductile material. Generally, the alloy undergoing cracking 18 almost inert in the environment, with essentially all of the oxidation being concentrated in the ctack. Not long ago, SCC was belleved to be corfined to only a few systems (combinations of metals and environments), but now it is recognized as a general phenomenon which occurs in all or nearly all types of alloys when the proper combination of heat treatment, stress, and environment exists.

There are two distinct phases to the SCC process: an lacubation period befcre a detectable crack forms, followed by a perfod of crack growth. The incubation period can be extremely varlable, in some cases lasting for years. The crack growth rate tends to be relatively fast and depends on the stress intensity at the tip of the crack and the envi ronment.

Cracks frequently - but not always - originate from the base of p1ts. Most investigators have indicated that the riajor purpose of the pit is to provide a stress concentration, but at least one investigator ${ }^{2}$ belleves that in some cases the primary function of the pit is to produce a solution of low pH within the pit which then initiates the crack.

SCC, in the context used here, implies that at lcast part of the cracking process involves an electrochemical dissolution of the metal at the tip of the crack and is sometimes referred to as "active-path corrcsion." (Th18 18 in contrast to hydrogen-embrittlement rracking to be discussed later.) That electrochemical processes are involved is 
shown by the fact that cracking can usually be provented, or even stopped once started, by cathodic polarization of the metallic object. In addition, as with crevice and pitting corrosion, the solution within the crack is of different composition from that of the bulk solution - in most cases more acid.

One major advance in studying SCC made during recent years has been the straining of test specimens at a very low constant rate while at the same time fixing the potential of the specimen relative to the environment. ${ }^{3}$ The effect of anodic polarization on most metals is to cause either active dissolution or passivation. In the electropotential range of active dissolution, the entire metal surfact corrodes rather than developing fsolated cracks. Similarly, in the potential region of stable passivity, the alloy is essentially inert and cracking does not occur. It is only in the potential regions where a transition between passivity and active dissolution occurs that cracking conditions are established. In these narrow potential regions the constant straining of the metal locally distupts passive fiims that are being formed, and active-path corrosion cracking occurs if the environment is capable of producing cracks. Once the response of an alloy to a given environment has been characterized (in terms of dissolution or passivation), it is only necessary to alter the potential efther to allow cracking or to prevent it. The potential may be altered by the addition of oxidizing or reducing substances to the solution, by polarization from an external source, or by electrically coupling it in the same solution to a metal or alloy of different electrochemical activity.

Other advances have been the use of precracked specimens to eliminate the ircubation period and the application of linear elastic fracture mechanics." Application of the latter methodology allows the direct use of laboratory data for predicting the behavior of large structural components for which fracture is a critical design consideration.

\section{Hydrogen Embrittlement}

Hydrogen-embrittlement cracking results from the entry of hydrogen into the metal, which reduces its ability to deform. In the strictest sense, hydrogen embrittlement is not a corrosion process; that is, 
oxidation does not occur along the fracture surface. However, entry of hydrogen into metal may result from corrosion on the metal surface. Whereas cathodic polarization stops active-path SCC, cathodic polarization of a stressed metal subject to hydrogen embrittlement usually either enhances cracking or has no effect on it.

Any process that generates atomic hydrogen on the surface of a susceptible metal can lead to hydrogen embrittlement. Cathodic polarization, either Erom internal or external sources, is the usual method of producing this hydrogen. The formation of molecular hydrogen involves the transitory existence of acomic hydrogen on the metal surface. Certain materials at the surface, notably $\mathrm{H}_{2} \mathrm{~S}$ and $\mathrm{H}_{3} \mathrm{As}$, inhibit the discharge of molecular hydrogen, thereby allowing a greater steady-state surface concentration of atomic hydrogen and, correspondingly, allowing a greater concentration of hydrogen to enter the metal. For example, $\mathrm{H}_{2} \mathrm{~S}$ cracking in sour gas and ofl wells is not active-path SCC but is hydrogenembrittlement cracking.

liyurogen embrittlement of high-strength steels is a relatively low-strain-rate phenomenon, because the cracking mechanism involves diffusion of hyorogen to sites where failure initiates. Atomic hydrogen concentrates in the region of highest stress, and time is required for a critical quantity of hydrogen to arrive before crack growth begins. Consequently, hydrogen embrittlement of high-strength steels is not detected with impact loading. Generally, the greater the hardness of a steel, the more likely it is to be embrittled; consequently, cold-working a steel increases its susceptibility to hydrogen erbritilement.

\section{CORROSION OF CARBON STEEL}

Since prestressed steel tendons are expected to retain their integrity for many years, and since in most applications the tendons are stressed to about $75 \%$ of their yield point, it is clear that even low general corrosion rates can lead to ultimate fallures by reduction of the cross-sectional area of the tendons. Thus, even though in the previous section it was indicated that most service failures result from localized attack, general or uniform attack must be considered 
when long-term service 11 fe 18 required. Furthermore, under certain conditions, even moderate general attack of high-strength steels can lead to hydrogen embrittlement.

In this section a few observat lons will be made about the genera] corrosion of steel, and this will be followed by a brief review of stress-corrosion cracking of steels. Finally, some pertinent literature on the corrosion of steels in concrete and organic greases will be revlewed.

General Corrosion of Steel in Aqueous Finvironments

The generas or unlform corrosion of iron and stece in aqueous solutions Is discussed in standard reference books, and only a few comments pertinent to more or less unform corrosion of steel tendons are presented here. Most of the following informat lon is based primarily on refs. 57 . The most Important variable In the corrosion of steel is the composition of the aqueous environment to whlch it is cexposed. When steel corrodes in afr-saturated water wh neutral pll, the anodic reaction is the conversion of Iron atons to ferrous lons, and the cathodic reaction is primarily the reduction of dissolved uxygen to hydroxyl lons, but a small part of the cathodic precess Involver reductlon of hydrogen lons to hydrogen. Remrval of oxygen from wuch solut lons slgnificantly reduces the corroston rate. Incteasing the hydrogen lon concentrat ton with a monoxldizlop acid increases the corrosion rate, and In deiterated solut lons the formaltion of hydrogen becomes the cathodic process. Under these condlteons, and probably even in alr-salurated water, some hydrogen can enter the metal and under proper ronditlous lead to embrittement. Increasing the alkalinity of water gratly reduces lts corrosivity, and at high enough alkalinlty the cmbrittlomint of steels at room temperature is unlikely.

Aerated neutral saline solutions arc particularly aggressive to steel, but if the solution is made sufficlently alkaline, essentially no at tack occurs; that 48 , the metal 18 passive. However, at some intermedlatc alkalf concentration where passivity is incomplete, severe pltting occurs. As Indicnted in the previous section, it 18 in those cases of Lorderline passlulty where nevere localized attack to to be expected. 
Specific Information on the general corrosion of steels with as much as $\mathbf{0 . 8 7}$ carbon was not found. However. In salt water, steels with carbon contents ranging from 0.05 to 0.27 carbon showed equivalent behavior. and it seens likely that this result would hold true for steels of still higher carbon content.

Stee $1 \mathrm{~s}$ somet Imes undergo unexpected corrosion in oxygen-free environments that contain sulfate lons. These high corrosion rates are frequently caused by anaerobic bacterta, which reduce sulfite to hydrogen sulfide as part of their metabolic process. This point is ralsed here because some greases that have been used in contact with stecl tendons contained organic sulfonates" which mity be reductble ro sulfides by bacterial action.

\section{Stress-Corrosion iracking of Stecl}

It was formerly believed that carbon steels were only suscept lble to act Ive-path SCC In caustlc or nitrate solut lons, and many studles with steels have been carried out in thesc environments. In both sodjum hydroxide ${ }^{3}$ and nitrate' solut lons the mode of fallure has been shown to be act Ive-path SCC. In caustic solutions the severlty of cracking Increases as both temperature and caust le concentrat lon increase. Generally, at room temperature, caust ic concentrat lon must be above Beveral percent to produce cracking. ${ }^{10}$ In nitrate solutlons, cracklng has been experlenced at or near room temperature, but lie s.ovetty Increases as the temperature licceases. 11,12 Generally, ti, ime to produce cracks decreases with increasing nitrate concentration, but this Is not universally true. For example, cracks formed in AISI 1080 stecel In $0.2 \mathrm{M} \mathrm{NH} \mathrm{NO}_{3}$ at $70^{\circ} \mathrm{C}$ but not in a saturated solution at the same temperature. ${ }^{12} \mathrm{Also}$, the time for cracking to occur Increases as the pH of the solution Incrcases. ${ }^{13}$

In recent years it has been shown that $m i l d$ and low-alloy stcels are suscep: Ible to cracking in many different environments. Thus, cracklng has been observed in liquid ammonia, "in water contaluing both co and $\mathrm{CO}_{2},{ }^{13}$ in solutions of carhonates and bicarbonates, ${ }^{16}$ in solut ions contalning acetate ions, 17 In phosphate solutions, ${ }^{18}$ and in solutions of ammonium carbonate. ${ }^{13}$ In addition, cracking in aqueous solutions of 
hydrocyanic acid has been reported, ${ }^{20}$ but in this case $i$ is probable that the cracks were due to hydrogen embrittlement. In most of these cases, cracking was demonstrated using the constant-strain-rate method combined with anodic polarization. The above list indicates that cracking can occur in many different environments, most of which were formerly considered to be innocuous.

Investigations with high-strength steels have been carried out by a number of investigators. Gilchrist and Narayan ${ }^{21}$ studied the behavior of a high-carbon $(0.837 \mathrm{c})$ eutectoid steel in several different metallurgical conditions and showed that cracking occurred in all microstructures, with fallures both by active-path corrosion and hydrogen embrittlement. In ferric sulfate solutions, fallures did not cccur without polarization, but either anodic or cathodic polarization produced cracks. In ammonium nitrate solttions, cracking occurred at the open-circuit potential and on anodic polarization, but cathodic polarization completely prevented at tack. Hydrogen sulfide produced cracking under a11 conditions, but chloride solutions containing sodium arsenate did not produce cracking at the open-circuit potential; cracking did occur, however, with ef ther anodic or cathodic polarization. In general, cold-drawn wires with a fine pearlitic structure were more resistant than quenched and tempered wires, although under the proper conditions both could be cracked.

Asphahani and Uhifg ${ }^{22}$ showed that when AISI 4140 steel was heattreated to hardnesses greater than $R_{c} 42$, cracking occurred in short times in boiling distilled water. Cold-rclling to $60 \%$ reduction $\left(R_{c} 46.5\right)$ resulted in immunity to cracking in boiling water and $3 \% \mathrm{NaC1}$, although in the latter environment, cracking could be produced by control of the potential. In another study by Uhlig et $a 1 .{ }^{23}$ a similar effect of cold-rolling was noted with furnace-cooled pearlitic steels. In this casse, steels with up to $0.2 \%$ carbon were susceptible to cracking in amonium nitrate solutions, but at greater carbon contents (up to $0.65 \%$ ) cracking did not occur. Cold-rolling of these steels produced immunity to cracking at all carbon levels.

Phelps ${ }^{24}$ noted that steels with yield strengths of about $200 \mathrm{ks} 1$ or greater are susceptible to cracking in a number of environments, including various natural atmospheres. 
The published information generally indicates that the higher the yfeld strength or hardness of a steel, the greater its tendency to crack. Cold-working the steel reduces, but does not totally eliminate, its susceptibility to cracking.

Because of failures experienced over the years in sour gas and oil wells, a very 1 arge amount of inforration about $\mathrm{H}_{2} \mathrm{~S}$ cracking has been generated. In these cases, $\mathrm{H}_{2} \mathrm{~S}$ leads to hydrogen embrittlement of susceptible steels. A recent review article ${ }^{25}$ summarizes the most significant facts on the subject, and only a few of the pertinent papers will be referenced here.

Accoraing to an NACE comittee, ${ }^{26}$ steels with hardnesses of $R_{c}<22$ are not expected to be susceptible to $\mathrm{H}_{2} \mathrm{~S}$ cracking. It has been shown that eracking o: susceptible steeis occurs with as little as $1 \mathrm{ppm} \mathrm{H}_{2} \mathrm{~S}$ in solution, ai though failures take much longer than with higher concentrations. $^{27}$ It has also been shown that the active species in aqueous solution i.s the undissocfated $\mathrm{H}_{2} \mathrm{~S}$ molecule, nnt $\mathrm{HS}^{-}$or $\mathrm{S}^{2-}$ ions. ${ }^{27,28}$ As a result, sulfide cracking is much more likely in acid solution ( $\mathrm{pH}$ of 2 to 6), where the major part of the sulfide exits as $\mathrm{H}_{2} \mathrm{~S}$, than in more alkaline solutions, where dissocfation of the $\mathrm{H}_{2} \mathrm{~S}$ takes place. However, fallures have been observed at solution $\mathrm{pH}$ values as high as 9.5. ${ }^{27,29}$ The presence of chloride ions in $\mathrm{H}_{2} \mathrm{~S}$ solutions produces no detertable effect on cracking, ${ }^{21,30}$ and the time to fallure is a minimum at $25^{\circ} \mathrm{C}$ according to Townsend, ${ }^{31}$ or $50^{\circ} \mathrm{C}$ according to Kawashima et al. ${ }^{28}$ Generally, cold work has a detrimental effect on $\mathrm{H}_{2} \mathrm{~S}$ cracking. ${ }^{32,33}$ For example, Baldy ${ }^{33}$ demonstrated that with an $\mathrm{N}-80$ steel, $1 \%$ cold work lowered its load carrying ability from 70-75,000 psi to 40-45,000 psi in $\mathrm{H}_{2} \mathrm{~S}$ solutions.

Uhlig ${ }^{34}$ noted that $3 \%$ NaC: solutions containing low concentrations of sulfites or thiosulfates produced cracks in stressed high-strength steels. Cracking did not occur with sulfate. He showed that sulfite and thiosulfate ions, but not sulfate fons, are reduced at a steel surface to hydrogen sulfide, which is the agent respcnsible for the cracking.

The evidence is very clear that even very low concentrations of $\mathrm{H}_{2} \mathrm{~S}$ in aqueous environments can produce cracking in high-strength steels. Fortunately, cracking is not 1ikely to occur in strongly alkaline environments such as those associated with concrete. But in acid, neutral, 
or slightly alkaline (pH of 7-9.5) solutions, cracking of such steels is highly probable with $\mathrm{H}_{2} \mathrm{~S}$ present. While $\mathrm{H}_{2} \mathrm{~S}$ factlitates hydrogen embrittlenent of steels, it should be noted that embrittlement can be produced in its absence. Generation of hydrogen on a steel surface, either from corrosioa reactions or by external polarization, may allow suficient atomic hydrogen to enter the steel to embrittle it.

Corrosion of Steel in Concrete and in Organic Compounds

To understand corrosion of metals in concrete, one must have at least a qualitative knowledge of the chemical nature of concrete. The following paragraph taken directly from a translation of a recent paper by Rieche $e^{35}$ is a brief description of the chemstry of concrete:

The setting and hardening of cement are consequences of chemical reacti ns between 1 ts components and the mixing water. The products of these reactions are gel-form, 1.e., extremely fine-grained $f$ iber, stieet, and tubular-shape particles which initially occur primarily in the water-filled spaces that occur between the cement particles and the additive particle grains. They form an intially local interwoven structure which is continuously strengthened by further products of hydration, and form a stiff bridgework connecting the solid particles. As a result of this, their mobility is increasingly restrficted, and the cement grout, mortar, or concrete sets. This gel, which is formed in the process of hardening, which contains water, but is rigid, and which forms as the result of progressive hydration, is permeated by a large number of gel and captllary pores. The gel pores exhibit diameters of the order of magnitude of only a few molecular diameters $\left(10^{-3}\right.$ to $\left.10^{-2} \mathrm{\mu m}\right)$ and run throughout the entire cement stone in a matrix-11ke fashion. In contrast, the cap1llary pores are in the range from $10^{-2}$ to $1 \mu \mathrm{m}$. The $\mathrm{Ca}(\mathrm{OH})_{2}$ formed in the hydration of the cement is deposited in both the gel pores and the capillary pores. Whereas the relatively wide capillary pores can dry out, depending on the humidity conditlons of the enviroment, the gel pores of the cement-glue are always filled with water, which is 1 tself saturated with calcium hydroxide. Just like the components c.f the concrete, the steel is also firmly surrounded by well-adhering cement gel. Thus the surface of a steel embedded in concrete $1 \mathrm{~s}$ directly surrounded by saturated $\mathrm{Ca}(\mathrm{OH})_{2}$ solution which exhibits a pH value of 12.6 , and thus causes the well-known corrosion protection of the steel by passivation. 
Thus it seems appropriate to perform corrosicn iests in an aqueous 1 ime solution which serves as a model for concrete, and some investigators have done :his.

Because of the alkaline nature of concrete, reinforcing cr prestressing steels have good corrosion resistance when the concrete is correctly formulated and applied. One method by which the alkalinity of the concrete is destroyed is through the process of carbonation, that $1 \mathrm{~s}$, the reaction of $\mathrm{CO}_{2}$ (usually from air) with the $\mathrm{Ca}(\mathrm{OH})_{2}$ in the concrete. This is a slow and continuing process and may, in time, penetrate the concrete to a depth of $1 / 4$ to $1 \mathrm{in}$., depending on the quality of the concrete. ${ }^{36}$ As a result of this reaction with $\mathrm{CO}_{2}$, the $\mathrm{pH}$ of the environment becomes as low as 9 to 9.5. At this $\mathrm{pH}$, steel 18 no longer passive, ${ }^{37}$ and corrosion of the steel is possible if water and oxygen are available. Furthermore, if the concrete contains sulfides, as in cases where blast-furnace slags are inrorporated in $1 t, \mathrm{H}_{2} \mathrm{~S}$ cracking can be expected at $\mathrm{pH}$ 's of 9 to $9.5 .27,29$

It is the permeability of the concrete as well as its thickness over refinforcing or prestressing stcel that determines how well the steel is protected. Obviously, highly permeable concretes will undergo carbonation and will allow the diffusion of corrosive materials in the environment $\left(\mathrm{Cl}^{-}, \mathrm{O}_{2}, \mathrm{H}_{2} \mathrm{O}, \mathrm{CO}_{2}\right)$ to the steel surface much more readily than will very dense concretes. The water-cement ratio is the primary factor in determining the permeabllity of consrete. Szilard ${ }^{37}$ recommends that the ratio not exceed 0.5 , with the preferred value being 0.40 . Even with dense, impermeable concretes, a minimum concrete thick.ess over the steel of $1 \mathrm{in}$. In mild environments and 2-1/? in. in marine environments is recommended.

Chloride is an important cause of the corrosion of steels, and a number of investigators have studied the effert of this ion on corrosion of steel in concrete. Hausmann, ${ }^{38}$ using saturated, as well as more dilute, lime sclutions with chloride additions as test media, concluded that in aerated solutions, corrosion of steel does not occur if the molar ratio of chloride to hydroxide ions 18 less than 0.6 ; in saturated lime solutions, attack began at a chloride concentration of about $700 \mathrm{ppm}$, 
but in the absence of oxygen much higher concentrations of chloride could be tolerated. Since Hausmann used unstressed specimens, SCC was not observed, but pitting and general corrosions were.

Monfore and Verbeck ${ }^{39}$ studied corrosion of prestressing vire (composition unspecified) embedded in various concretes containing added $\mathrm{CaCl}_{2}$. The wires were externally loaded to $140 \mathrm{ksl}$, and after 28 days, corrosion in the form of pitting was observed on all specimens. Cold-drawn wires supplied by the manufacturer (presumably uing cooled and lubricated dies) showed no tendency to crack, but wire cold-drawn in the laboratory, using an uncooled and unlubricated die, tended to develop longitudinal cracks, that is, cracks parallel to the direction of applied stress. No sign of conventional SCC was found. Treadaway ${ }^{40}$ al so studied the behavior of cold-drawn steel ( $0.8 \% \mathrm{C}$ ) stressed to $70 \%$ of its ultimate tensile strength in concrete containing 2 to $5 \pi \mathrm{CaCl}_{2}$. After periods ranging from 2 to 27 months, no cracks were found, although severe general corrosion and pitting occurred, the extent of attack being greater the higher the $\mathrm{CaCl}_{2}$ concentration. Similar results were obtained by Godfrey. ${ }^{4}$ On the other hand, Rieche ${ }^{35}$ showed that cracking as well as pitting of carbon steel $(0.4 \% \mathrm{C})$ could occur in saturated limewater to which chloride was added, if the applied stress and chloride concentri ion were high enough. Over a large concentration range, open-circuit potentials fell within an SCC region of potential so that cracks in stressed materials could develop spontaneously. His data indicated that at chloride concentrations below about $0.01 \mathrm{M}(350 \mathrm{ppm})$, cracking should not ve possible. He therefore postulated that limiting the chloride concentration to a maximum of $300 \mathrm{ppm}$ would prevent SCC. The reason why cracking was observed by Rieche and not by the other investigators ${ }^{39-41}$ is not completely clear from the information presented. It has been noted by several investigators $35,36,39$ that the components of cements are capable of chemically binding chloride so that it 18 not avallable to produce corrosion, and this may partly explain the difference; that 18, the "effective" chloride concentration in the concrete could have been much less than the total chloride, perhaps less than $0.01 \mathrm{M}$. Regardless of the reason, it is clear that calctum chloride should not be used as an additfve tc concrete that is to be in contact with steel, nor should seawater or unwashed sea sand be used in mixing the concrete. 
Generally, $\mathrm{H}_{2} \mathrm{~S}$ cracking of steel in concrete is not expe:ted because of the high al'alinity of concrete, but Rieche ${ }^{35}$ and Cornet ${ }^{42}$ report apparent cases of ewiritzlement caused by the presence of $\mathrm{H}_{2} \mathrm{~S}$ where the alkalinity of the concrete was diminished or when cracks in the concrete allowed $\mathrm{H}_{2} \mathrm{~S}$ to come in contact with steel. On the other hand, Rieche $\mathrm{e}^{35}$ showed th:t in saturate $\mathbf{J}$ lime solutions containing $0.02 \mathrm{~K}$ r greater $\mathrm{CaS}$, cracking of high-strength steels could occur. Lsing two similar steels, each containing about $0.4 \%$ carbon, he showed that neither cracked on cathodic polarization, but both cracked on anodic po drization. Cne of the steels cracked at the open-circuit potential, whoreas anodic polarization was necessary to produce cracking in the other. With only $\mathrm{Cd}_{\mathrm{d}}(\mathrm{OH})_{2}$ solutions. cracking could not be produced under any conditions. This appears to be the first time that active-path SCC has been reported in the presence of sulfide.

Rieche $^{35}$ also examined the effect of nitrate concentration in saturated $\mathrm{Ca}(\mathrm{OH})_{2}$ solutions on the cracking of steel and showed that at nitrate concentrations greater than $0.01 \mathrm{M}\left(620 \mathrm{ppm} \mathrm{NC^{3 }}\right)$, cracking occurred only on anodic polarization. Regardless of potential, no failures occurred at concentrations of $0.01 M$ or less.

The importance of pockets of air in concrete that are in contact with steel has been pointed out by several invistigators. $36,38,39,43$ All data indicate that steel corrodes more severely at voids in the concrete than on adjoining areas covered with cement. Thus in filling conduits containing prestressing steel. tendons, care must be taken to prevent such air pockets from forming; compressed air should never be used to force grouts into conduits.

One form of failure that is possible with grouter? tendons is dissimilar-metal (galvanic) corrosion. If, for example, a stressed tendon embedded :-n grout is electrically coupled with a more active metal such as aluminum or zinc, the tendon becomes the cathode of the cell and under some conditions hydrogen can be liberated on its surface, enter the metal, and embrittle it. Examples of such failures are presented in the literature. ${ }^{35,64}$ The hydrogen embrittlement of galvanized high-strength ateels has also been studied; 43 when zinc was removed from small areas of the surface and the steel placed in concrete, cracking 
usually occurred at about 802 of the yleld stress. Furthermore, examples of cracking of prestressed steels coupled to wre noble wetals have been cited by Rieche, ${ }^{35}$ and in these cases the cracking was apparently due to active-path SCC. In addition to dissimilar-aetal cells, similar types of alectrochemical cells may develop because of differences in concentration of chloride, oxygen, acidity, and possibly oti.er materials along a wire. Stray dc currents such as frow at improperly grounded welding machine can also produre corrosion.

From the above considerations it is apparent that the corrosion of steels in concrete is not a problem if simple and reasonable precautions are taken in making and applying the grout or concrete.

In one reported incidence of corrosfon of steel tendons that were presumably protected by an organic substance, stray currents appear to have been responsible for the observed damage. A heavy petroleu grease containing a sodium petroleum sulphonate as a wetting agent coated all surfaces. Contamination of the coated tendons with water resulted in emulsification of the grease on part of each tendon. Examination of these cendons six months after installation in the ducts showed pits up to $2 \mathrm{~m}$ deep under both emulsifled and sound grease. In laboratory tests with identical tendons, some coated with emulsified grease and some with sound grease, no pits or otiner forms of at tack occurred, but on anodic polarizatiun, pits formed identical to those observed in the ducts.

The only other case of fallures of tendons proterted by organic materlals that we are aware of are those observed in a concrete thermal cyclinder test at Oak Ridge National Laboratory and referred to in the Introduction. ' In that case the tendons were protected by a wax, but water inadvertently entered some of the ducts containing the tendons. In adfition, improperly formulated epoxy resin in the cylinuer added high concentrations of nitrogen compounds to the environment. It was suspected that a nitroge: compound, possibly ammonium nitrate, was the responsible agent.

Unfortunately, the information avallable on the behavior of steels when coated with greases or other protective organic compounds is very 1imited. Also, the chemical stability of these compounds over very long periods of time and the effects of any degradation products on corrosion products on corrosion are not well known. 
EXPERIMENTAL INVESTIGATION

\section{Experinental Considerations}

The approach to studying stress-currosion cracking that was used in many former investigations involved exposing candidate materials, stressed to sowe predetermined level, in a given environment, and measuring the time to failure. When specimens cracked in less time than the duration of the test, the susceptibility of the material to cracking was established. If the material did not crack during the test, the materdal was considered resistant to cracking in the environment. To be sure of immunity, however, one would have to expose the stressed material for very long times - probably as long as the intended use of the object. Obviously this is not practical in most cases. Furthermore, cracking is statistical in nature, and to obtain significant data, relatively large numbers of specimens should be exposed under each test condition, yielding a distribution of fallure times. Thus, with conventional stress-corrosion cracking tests, one is usually faced with large numbers of tests conducted for long periods of time if onc is to have confidence in knowing the susceptibility of a given alloy to cracking in a specific environment.

Another apprcach to the study of stress-corrosion cracking uses the constant-strain-rate method as described by Humphries and Parkins. ${ }^{3}$ With this technique, a tensile-type specimen is exposed to the test enviroment and is pulled at a very slow constant rate until fracture occurs, usually within a period of a few days at most. By comparing reduction in area, elongation, and/or time to failure under different conditions, the relative susceptibility of a material to cracking in different environments can be established. Examination of thic fracture surface and metallographic examinetion of the surface in the gage section can provide additional information about the fracture process. Additional Insight into the cracking process and the influence of changes in the oxidizing potential of the solution can be obtained by Impressing an electrochemical potential on the specimen using a potentiostat and studying the time to fallure at different potentials. Even though all 
the suttleties of the constant-strain-rate technique may not be fully understood, the data obtained from these tests provide engineering information on the properties of materials under controlled environmental conditions. While this test method provides information on the tendency of a material tu crack, it does not provide direct information on the statistical probability of cracking at a specific stress level.

In view of the above considerations and because of budgetary and time limitations, the slow-strain-rate method was used to examine the cracking tendency of cold-worked AISI 1080 steel tendon wires in selected environments. The general corroston rate of the steel under several conditions was also determined. Most of the experiments were conducted in near neutral environments because at these $\mathrm{pH}$ values attack is usually more severe than in alkaline solutions such as exist in concretes. Also, no attempt was made to study pitting and the cracking that frequently originates at the base of pits.

\section{Experimental Procedures}

The tensile tests described here were couducted on the center straight wire of a seven-wire tendon made from cold-worked AISI 1080 stee1 and conforming to ASTM A 416, grade 270. The diameter of the wire was $5 \mathrm{fm}(0.20 \mathrm{in.})$, and for the present test the surface of the wire was used as recefved, except surface rust was removed with fine emery paper. For the stress-corrosion tests, the wire in the presence of the test environment was strained at a constant rate in an Instruia tensile machine which had a maximum capacity of $4500 \mathrm{~kg}(10,000 \mathrm{lb})$. The length between the grjps was $0.20 \mathrm{~m}$ ( $8 \mathrm{in.})$, but only the center 75-mm (3-in,) length was exposed to the solution, which was held in a polyuinyl chloride bottle. A gage section was not rachined in the wire, since we wanted to retain the original surface condition of the colddrawn wire. To prevent any unusual effects at the solution-air interface or in the crevice when the wire passed through a stopper in the bottom of the bottle, the 75-m test length was defined by the use of a stop-ofi varnish and was covered with solution both above and below the test section. All tests were conducted at the open-circuit corrosion potential. 
The minimum crosshead speed of the tensile machine was $8.33 \times 10^{-2} \mathrm{~mm} / \mathrm{s}$ (0.0002 $\mathrm{in.} / \mathrm{min})$ and with the $0.20-\mathrm{m}$ length of the specimen corresponded to a strain rate of $4.17 \times 10^{-7} / \mathrm{s}$. This minimum strain rate was used in all tests except two. After a sperimen failed a 25-m (1-in.) length, including one failed end, was metallographically polished alung the axis to look for cracks on the surface exposed to the solution.

The general corrosion rates of AISI 1080 steel tendon wires vere determined in several different aqueous environments. In one series of tests, weighed $25-\mathrm{mm}(1-\mathrm{in}$.) lengths of wire were totally immersed in different solutions. In these tests the 5-mm-diam wires were placed in 6-mm-diam glass test tubes and were immersed to a defth of about $10 \mathrm{~mm}$ above the specimen height in different test solutions, which incluried dilute solutions of chloride, nitrate, and sulfate, and potable and distilled water. The total volume of solution was anly abour $5 n n \mathrm{~mm}^{3}$, and these conditions were intended to simulate those that could exist in the interstices of wires in the tendons. Evaporative losses were replaced periodically with distilled water. Although the tubes were open to the air, the small clearance between the tube wall and the specimen restricted access of oxygen th the specimen. As corrosion proceeded, the buildup of corrosion products on the specimen further limited access of oxygen. These tests lasted for $2000 \mathrm{hr}$, but duplicate specimens were removed from test after $1000 \mathrm{hr}$. All specimens were descaled in Clarke's solution ${ }^{46}\left(2 \mathrm{~g} \mathrm{Sb}_{2} \mathrm{O}_{3}\right.$ and $5 \mathrm{~g} \mathrm{SnCl} 2$ dissolved in $100 \mathrm{ml}$ of $37 \% \mathrm{HCl}$ ) before final weighing. Other specimens that had been exposed to some of the solutions for $2000 \mathrm{hr}$ were analyzed for their hydrogen content. In these cases the specimens remained in test until analyzed. The corrosion product was then removed with emery paper, and the hydrogen in the steel was determined by vacuum fusion.

In another series of tests, single wires $0.3 \mathrm{~m}$ (12 in.) long were immersed in dilute solutions of $\mathrm{Na}_{2} \mathrm{SO}_{4}$ and $\mathrm{NaCl}$ and in distilled water at room temperature for nine months. The volume of water was about 1 liter and was exposed to the air; water lost by evaporation was replaced every few days. The test specimens extended above the water level so that attack at the water-air interface could be examined. At the end of the test the specimens were descaled in Clarke's solution, and the diameter of the wire above and below the waterline was compared. 


\section{Resuits}

The results obtained from the constant-strain-rate tests are shown in Table 1. Tests 1 and 2 confirmed that the tensile strength conformed to ASM A 416 grade 270 (mintmum tensile strength of $190 \mathrm{~kg} / \mathrm{mm}^{2}$ ). Since

Table 1. Results Obtained from Constant-Strain-Rate ${ }^{a}$ Tests with AISI 1080 Steel Wires

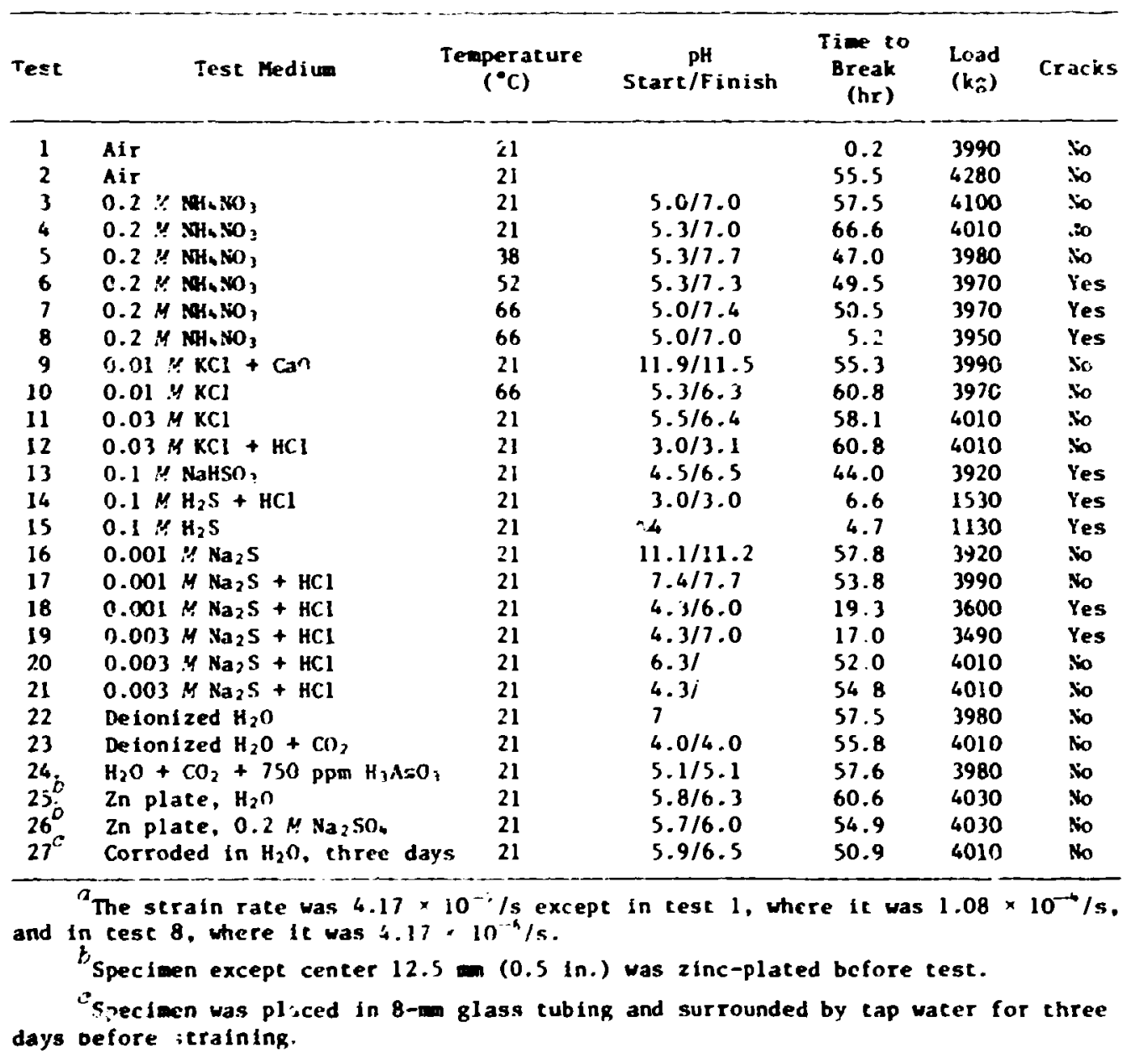

the entire wire was of constant diameter, there was concern that failure would occur preferentiaily at the grips, but this problew was not encountered. Tests 3 through 8 were conducted with $0.2 \mathrm{MNH}_{4} \mathrm{NO}_{3}$, since this reagent was suspected of causing failure in the thermal cylinder test at Oak RIdge National Laboratory. ${ }^{1}$ No signs of cracks were found in specimens tested at 21 and $38^{\circ} \mathrm{C}$, but cracks were found at 52 and $66^{\circ} \mathrm{C}$. 
Figure 1 shows representative views of the specimens tested at the four temperatures when the strain rate was $4.17 \times 10^{-7} / \mathrm{s}$. At a tenfoid greater strain rate (test 8 ), cracks were noted, but the depth of penetration was less than at the lower strain rate. Even though cracks were evident in the steel at the two higher temperatures, no effect on either the time to failure or on the load at failure was noted. The large diameter of the wire and the relatively slow rate of crack propagation were responsible for this observation. With a smaller-diameter test section and a slower strain rate, the effect of the cracks on the time to fallure would have been obvious. The formation of cracks at $66^{\circ} \mathrm{C}$ and the absence of cracks at $21^{\circ} \mathrm{C}$ agree with the results obtained with U-bend specimens exposed to the same solution; U-bends cracked in a few days at $66^{\circ} \mathrm{C}$ but remained intact at $21^{\circ} \mathrm{C}$ during 100 -day tests.

No cracks were found in any of the specimens exposed to chloridecontaining environments (tests 9-12), regardless of the $\mathrm{pH}$ of the solution. This is in conformance with the generally accepted bellef that chloride ion is not an aggressive cracking agent for steels of this iype, although Rieche ${ }^{35}$ did observe cracking in a steel of $0.4 \%$ carbon content in the presence of chloride ions.

There appeared to be some evidence of cracking in $0.1 \mathrm{M} \mathrm{NaHSO}_{3}$ (test 13) as 11lustrated in Fig. 2, which shows one of several localized penetrations along the surface of the wire near the falled region. Only in the case of amonium nitrate solutions were similar penetrations observed. Obviously, the ammonium bisulfite was not reduced to hydrogen sulfide at a rate fast enough to produce hydrogen embrittlement as reported by Uhlig. ${ }^{34}$

As expected, $\mathrm{H}_{2} \mathrm{~S}$ produced rapid fallure in the test specimens when the $\mathrm{pH}$ was low and the $\mathrm{H}_{2} \mathrm{~S}$ concentration was relatively high (tests 14 and 15). Figure 3 shows cracks observed in test 15. In $0.001 \mathrm{M} \mathrm{Na} S$ at a $\mathrm{pH}$ of 11.1 or 7.4 (tests 16 and 17), no cracking was observed, but when the pH was adjusted to 4.3 (test 18), cracking occurred. At this lower concentration, fallure took longer than at the higher suifide concentrations, and the cracks were generally finer (P1g. 4). Cracking occurred slightly faster when the $\mathrm{Na}_{2} \mathrm{~S}$ concentration was increased to $0.003 . M$ (test 19), but the nature of the cracks was the same as shown 

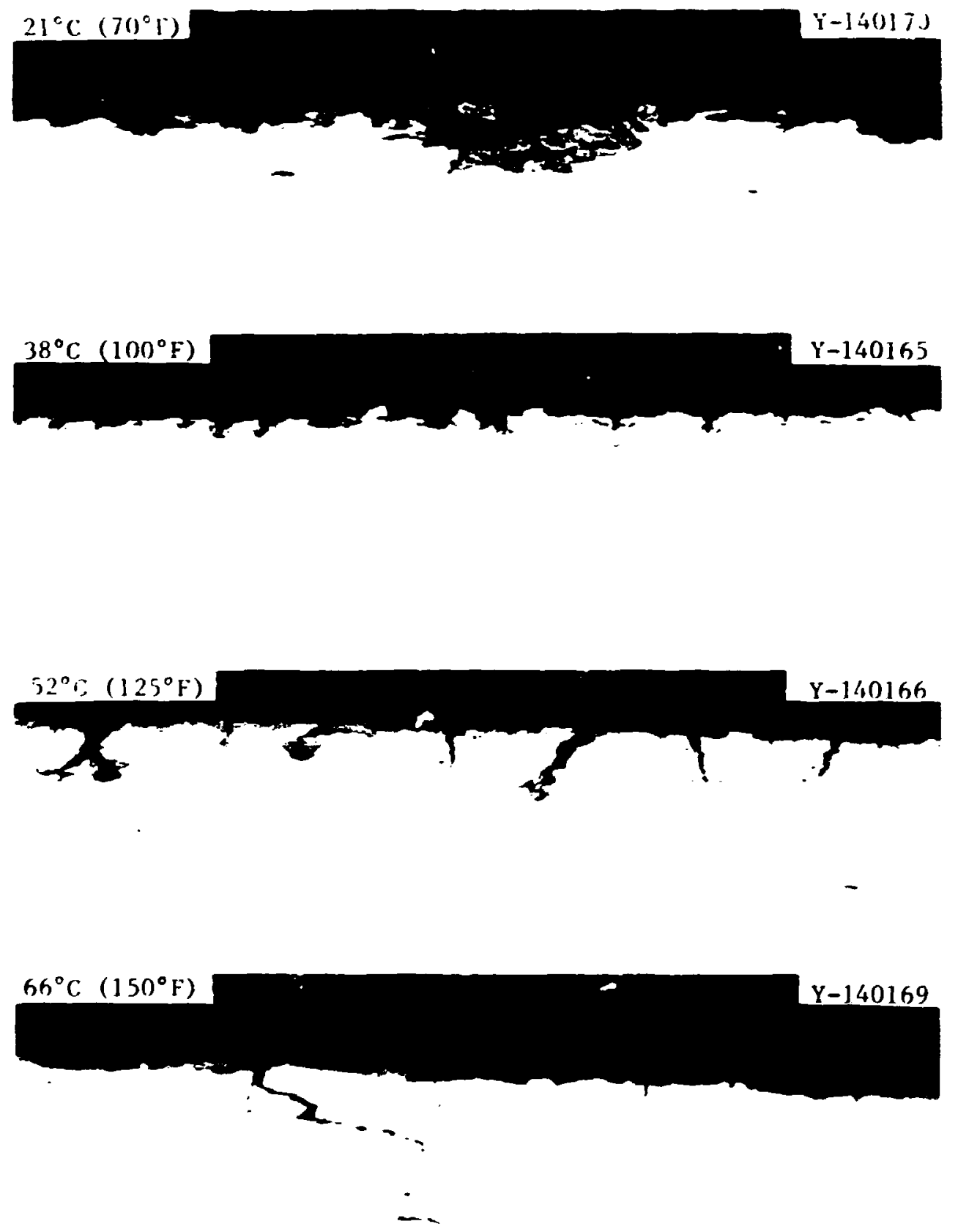

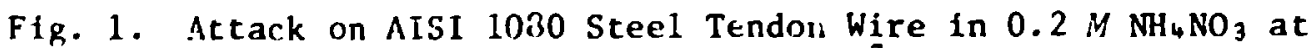
Different Temperatures. Strain rate, $4.17 \times 10^{-7} / \mathrm{s} .250 \times$. 


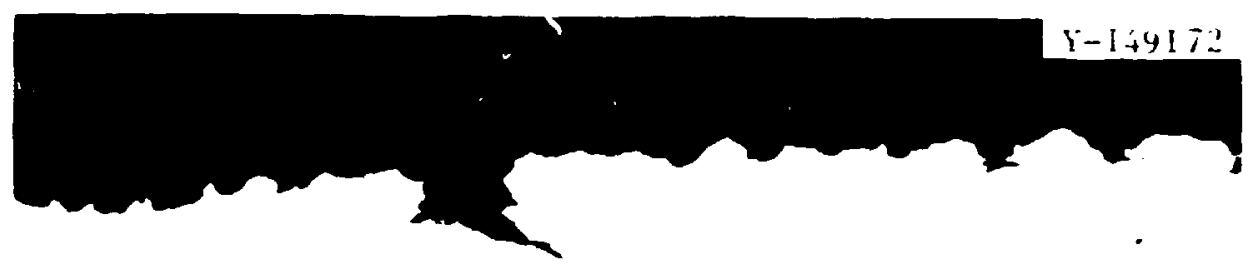

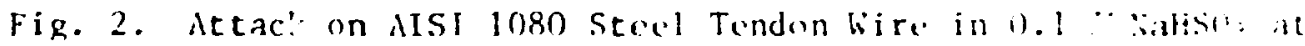
Room Temperature. $100 \%$ 

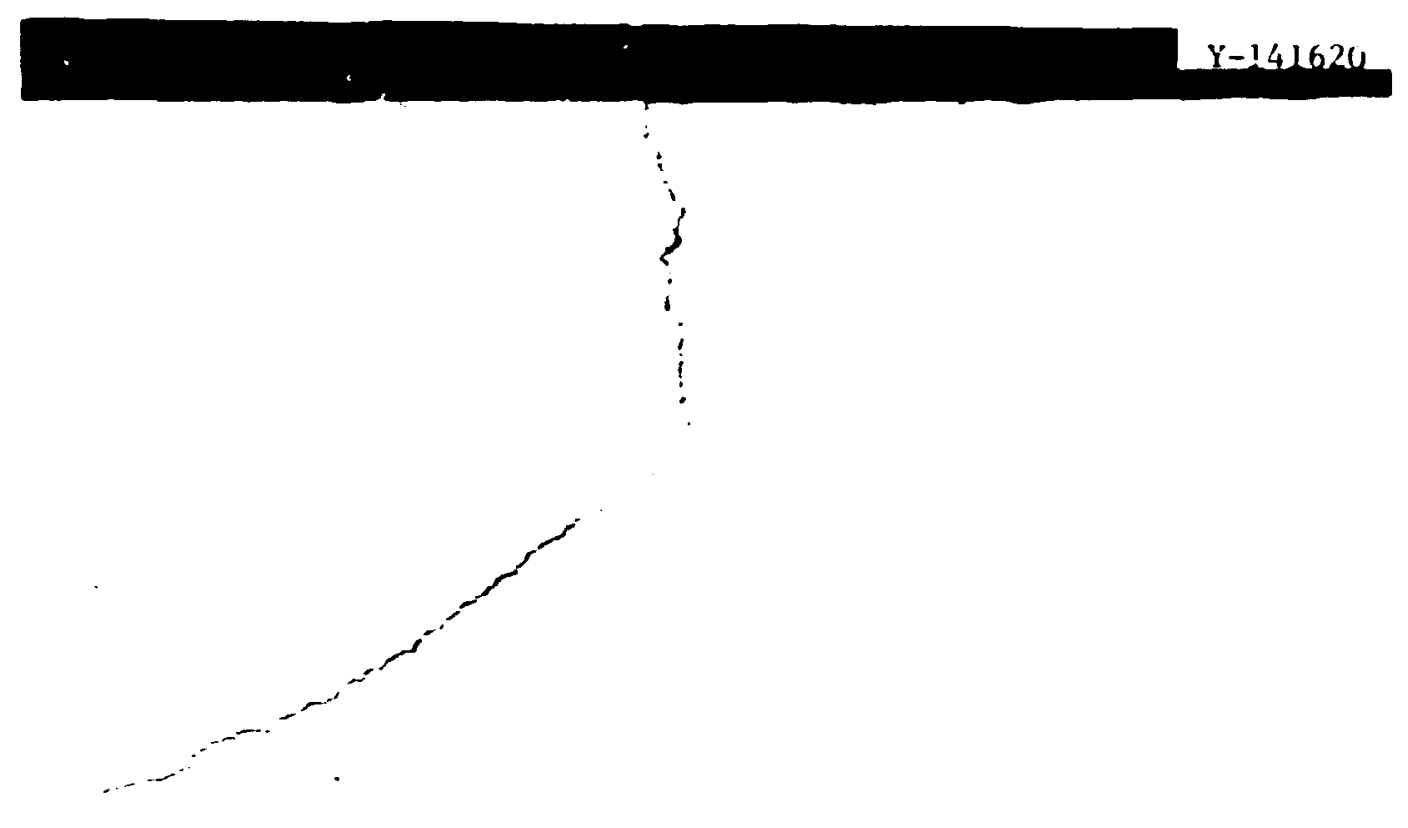

Fig. 3. Cracks formed in AISI 1080 steel wire in $0.1 \mathrm{MH}_{2} \mathrm{~S}(\mathrm{pH}$, 4) at Room Temperature. 100x. 


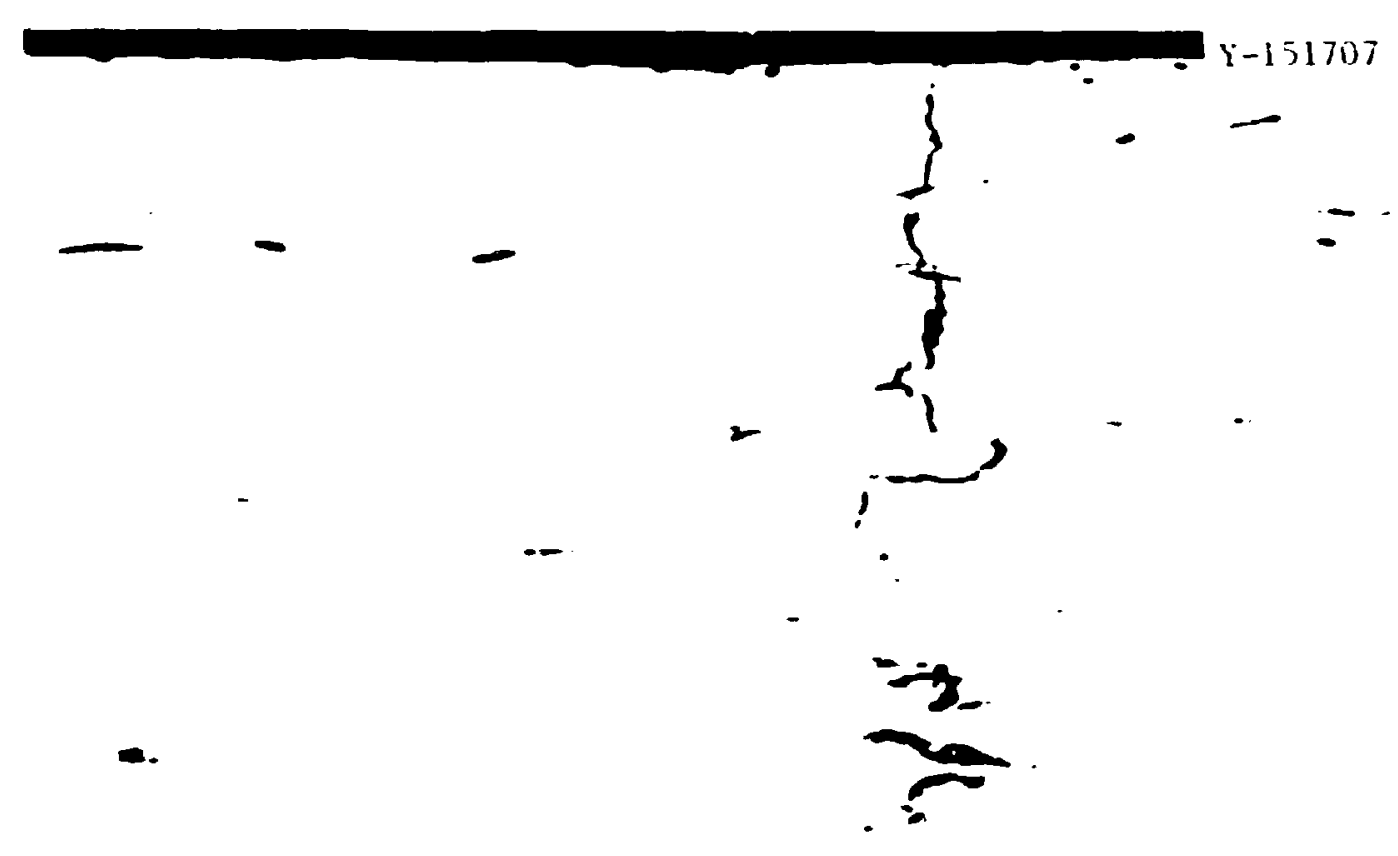

Fig. 4. Crack:; Formed in AISI 1080 Steel iendon bire in $0.001 \Omega$ $\mathrm{Na}_{2} \mathrm{~S}$ with pil Adjusted to 4.3 .

in Fig. 4. When the sulfide concentration was reduced to $0.0003 \mathrm{M}$ (tests 20 and 21), no cracking was observed. Although the solutions were sparged with nitrogen before the $\mathrm{Na}_{2} \mathrm{~S}$ was added and the polyvinyl chloride bottle coritaining the solution was stoppered, it is probable that the small amount of sulfide in the solution was oxidized early in the test to sulcur by traces of oxygen in the bottle. Fertainly, at the end of the test no odor of hydrogen sulfide could be detected above the solution.

Deionized water either by itself (test 22) or with carbon dioxide bubbling through it (test 23) did not produce cracking. Cracking also did not occur when the steel was corroded in water tor three days before the specimen was pulled. Similarly, the presence of carbon dioxide and $750 \mathrm{ppm}$ arsenlous acid in water failed to produce cracks (test 24). In the latter case the wire was heavily fickled $i$ : uninhtbited hydrochloric acid and remained in the test solution overnight before the specimen was pulled. 
Two specimens (tests 25 and 26) were electroplated with $0.013 \mathrm{~mm}$ (0.0005 in.) of zinc except for a 12.5-m (0.5-in.) length in the middle of the wire. When exposed to the aqueous environment, the unplated area was cathodic to the zinc, and the possibility of hydrogen embrittlement existed. However, neither in pure water nor in $0.2 \mathrm{M} \mathrm{Na}_{2} \mathrm{SO}_{4}$ did cracking occur.

In all cases except where cracking occurred in the presence of sulfide, cup-cone-type fallures were observed, and the reduction in area varied randonly between 36 and $43 \%$ except in test 3 , when 1 was $47 \%$. In tests 14 and 15, nn reduction in area could be measured, and in tests 18 and 19 the reduction in area was only $4 \%$. Even though cracks were not observed in most cases, most of the failures occurred in the 75-m (3-in.) length exposed to the test solution. Only in tests $12,16,20,21,25$, 26 , and 27 did the wire break outside the solution-exposed length, and in tests 25 and 26 the exposed steel was cathodically protected by zinc. The above observation suggests that general corrosion of the steel contributed to the faflure process, although the amount of corrosion that occurred during the test perfod must have been very small.

The corrosion rates observed on the terdon wires exposed to the very small volumes of solutions are shown in Table 2. After $1000 \mathrm{hr}$ in some cases and in most cases after $2000 \mathrm{hr}$, the volume of corrosion products that had formed prevented removal of the specimen from the glass tube, and it was necessary to break the tube to recover the specimen. Table 2 si.ows that under these conditions, corrosion rates were low and nearly independent of the environment except in one case; both specimens exposed for $2000 \mathrm{hr}$ in $0.001 \mathrm{M} \mathrm{NaNO}_{3}$ corroded at rates of nearly $25 \mu \mathrm{m} /$ year ( 1 mpy). There was no ignificant localized attack in any case.

The hydrogen content of specimens exposed for $2000 \mathrm{hr}$ are shown in Table 3. The control specimen had been exposed only to afr. The hydrogen content of the steel was low, but exposure to any of the environments prcduced a detectable increase of the hydrogen content. Comparison of these results with those in Table 2 shows that the amount of hydrogen in the steel was not proportional to the corrosion rate. However, the smaller hydrogen content in the nitrate solution may be related to the oxid1z..ng nature of the nitrate ion. 
Table 2. Coiroston ố AISI 1080 Steel

Tendon Wires in Different

Environments

\begin{tabular}{|c|c|c|}
\hline Test Environment & $\begin{array}{l}\text { Time } \\
\text { (hr) }\end{array}$ & $\begin{array}{l}\text { Average Corrosion } \\
\text { Rate ( } \mu \mathrm{m} / \text { year) }\end{array}$ \\
\hline Potable water & $\begin{array}{l}1000 \\
2000\end{array}$ & $\begin{array}{l}5.8 \\
5.3\end{array}$ \\
\hline Distilled water & $\begin{array}{l}1000 \\
2000\end{array}$ & $\begin{array}{l}5.1 \\
5.3\end{array}$ \\
\hline $0.03 M \mathrm{NaCl}$ & $\begin{array}{l}1000 \\
2000\end{array}$ & $\begin{array}{l}6.6 \\
7.9\end{array}$ \\
\hline $0.01 M \mathrm{NaCl}$ & $\begin{array}{l}1000 \\
2000\end{array}$ & $\begin{array}{l}6.4 \\
9.7\end{array}$ \\
\hline $0.0:-M \mathrm{NaNO}_{3}$ & $\begin{array}{l}1000 \\
2000\end{array}$ & $\begin{array}{r}11.2 \\
8.1\end{array}$ \\
\hline $0.001 / / \mathrm{NaNO}_{3}$ & $\begin{array}{l}1000 \\
2000\end{array}$ & $\begin{array}{r}7.4 \\
23.1\end{array}$ \\
\hline $0.2 \mathrm{M} \mathrm{Na}_{2} \mathrm{SO}_{4}$ & $\begin{array}{l}1000 \\
2000\end{array}$ & $\begin{array}{r}8.9 \\
13.5\end{array}$ \\
\hline $0.02 \mathrm{M} \mathrm{Na}_{2} \mathrm{SO}_{4}$ & $\begin{array}{l}1000 \\
2000\end{array}$ & $\begin{array}{r}7.6 \\
13.2\end{array}$ \\
\hline $0.002 \mathrm{M} \mathrm{Na}_{2} \mathrm{SO}_{4}$ & $\begin{array}{l}1000 \\
2000\end{array}$ & $\begin{array}{l}5.8 \\
7.6\end{array}$ \\
\hline
\end{tabular}

Table 3. Hydrogen Content of AISI 1080 Steel Tendon Wires Exposed

to Different Environments for $2000 \mathrm{hr}$ at Room

Temperature

\begin{tabular}{lc}
\hline Environment & $\begin{array}{c}\text { Hydrogen Content } \\
(\mathrm{ppm})\end{array}$ \\
\hline Control & 1.14 \\
Potable water & 1.99 \\
$0.03 \mathrm{M} \mathrm{NaCl}_{0.01}$ & 3.51 \\
$0.0 \mathrm{NaNO}_{3}$ & 1.65 \\
$0.2 \mathrm{M} \mathrm{Na}_{2} \mathrm{SO}_{4}$ & 2.89 \\
\hline
\end{tabular}


The wires (0.30-m lengths) exposed to large volumes of solution that was freely exposed to air showed considerably wore corrosion than did the short specimens exposed to small volumes of solution with restricted access to oxygen (air). Table 4 shows the corrosion rate calculated fron the difference in diameter above and below the waterline after exposures of nine wonths.

Table 4. Corrosion Rates for AISI 1080 Steel Tendon Wires Exposed for Mine Honths to Solutions with Free Access to Air

\begin{tabular}{lc}
\hline Enviroment & $\begin{array}{c}\text { Corrosion Rate } \\
(\mu \mathrm{m} / \text { year })\end{array}$ \\
\hline Dist11led water & 76 \\
$0.05 \mathrm{M} \mathrm{NaCl}$ & 152 \\
$0.1 \mathrm{M} \mathrm{Na} \mathrm{SO}_{4}$ & 254 \\
\hline
\end{tabular}

Table 4 also shows that with free access of oxygen the steel corroded at a greater rate than when access to oxygen was limited. In all of the above cases, attack was greatest at the solution-air interface, but localized attack in the for of pitting was noted below the waterline in all cases. Figures 5, 6, ind 7 show the corrosion observed. In each figure (a) shows attack at the waterline, (b) shows reprer entative attack on the submerged part of the wire, and (c) compares a cross section through the steel at the waterline with one above the waterine and illustrates the maximum reduction in cross sections produced by corrosion.

\section{DISCUSSION}

The experimental results obtained with the AISI 1080 steel are in general agreement with published data. racking was observed in the

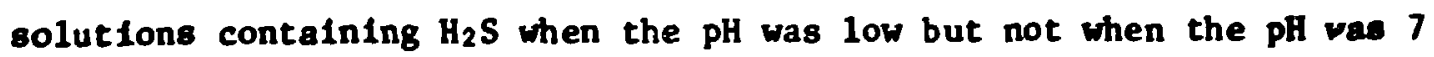
or above. Thus, steel tendons surrounded by correctly formulated and 


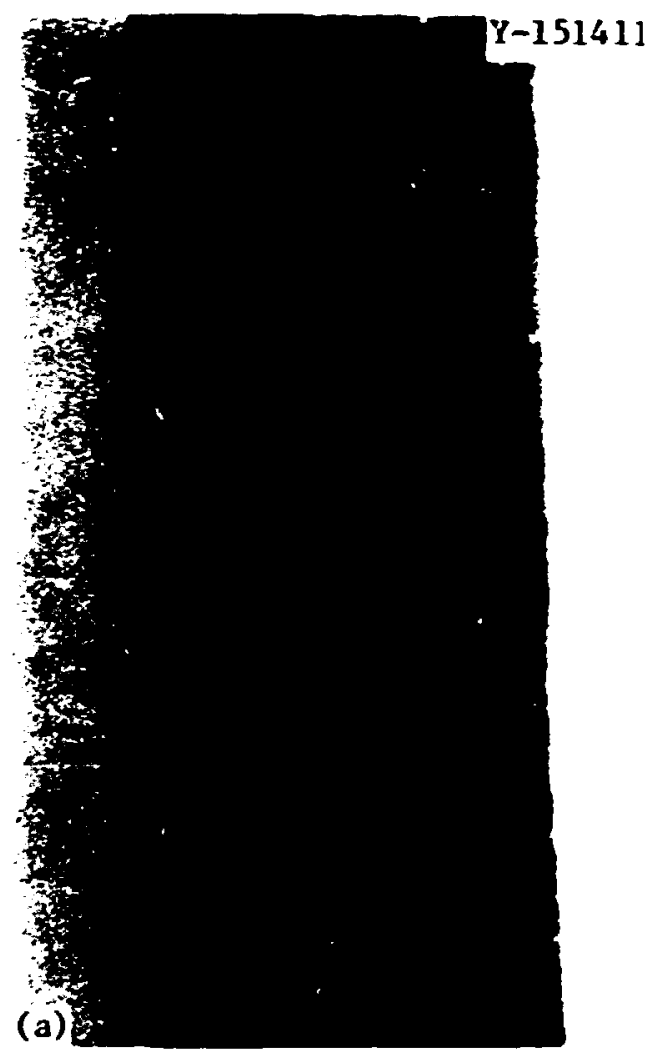

(b)
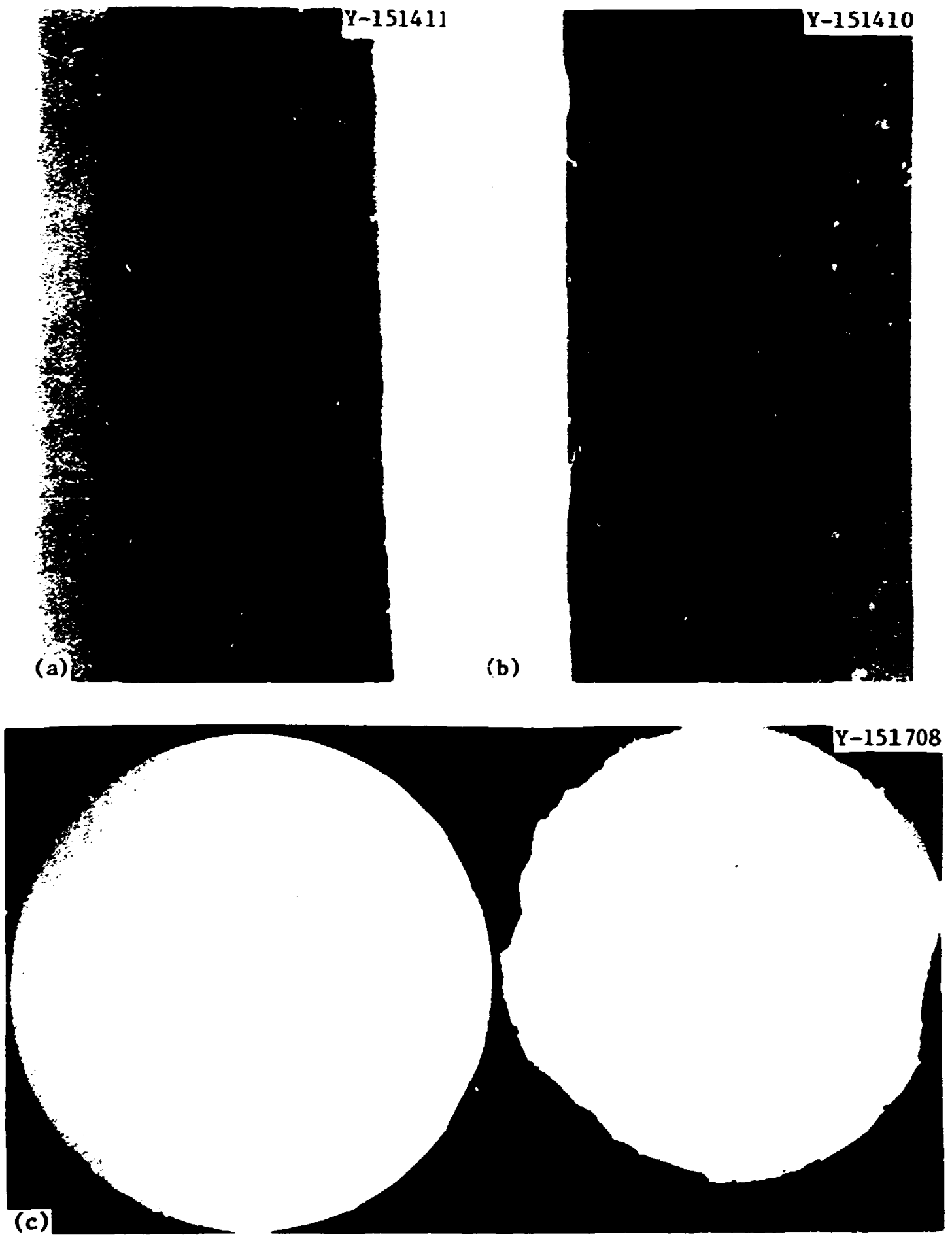

F1g. 5. Corrosion of AISI 1080 Steel Tendon Wire During a 9-Honth Exposure to Dist1lled Water at Room Temperature. (a) Attack at waterline; (b) attack on submerged wire; (c) comparison of cross sections at the waterline and above the waterilne. Diameter of wire is $5 \mathrm{~mm}$. 

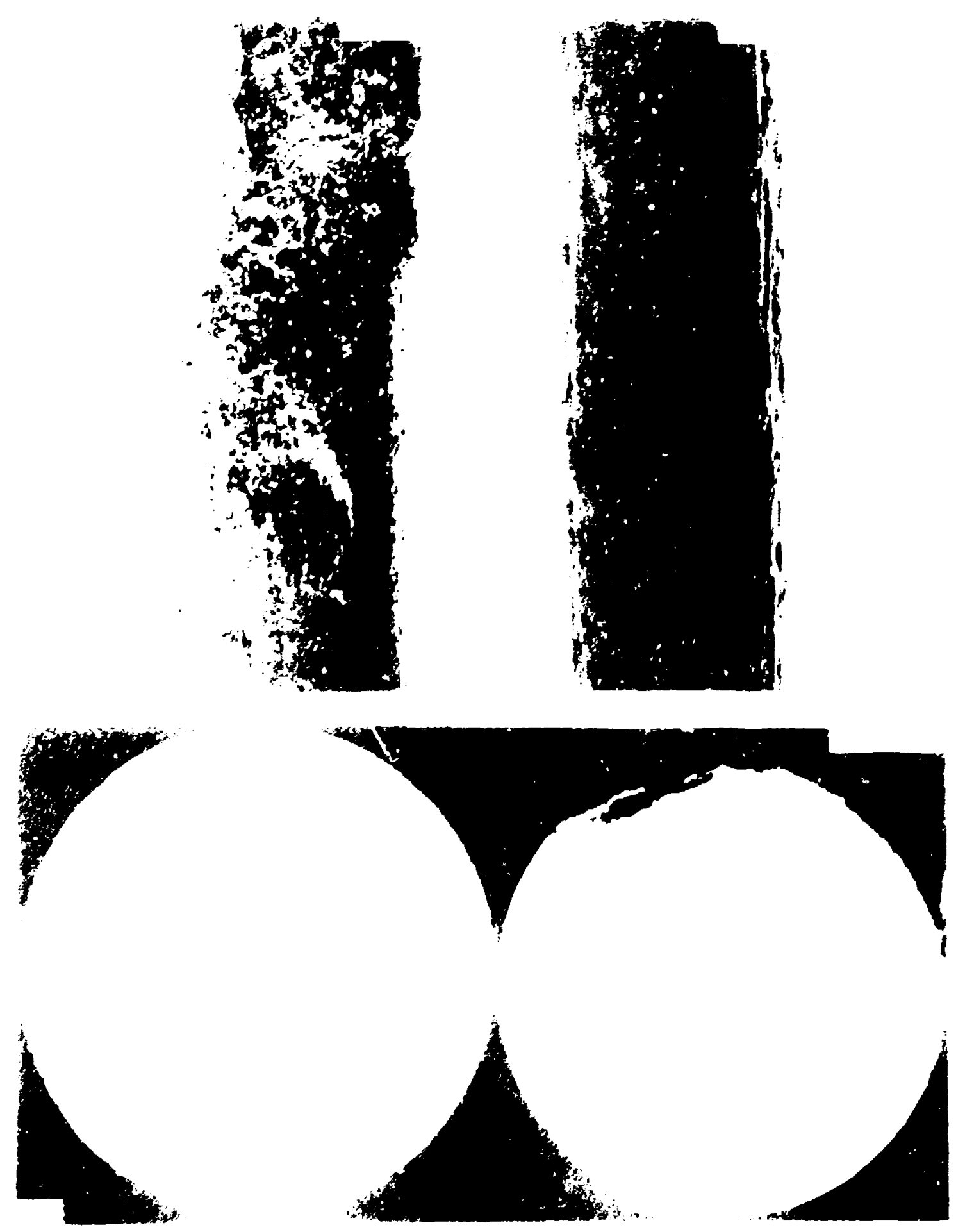

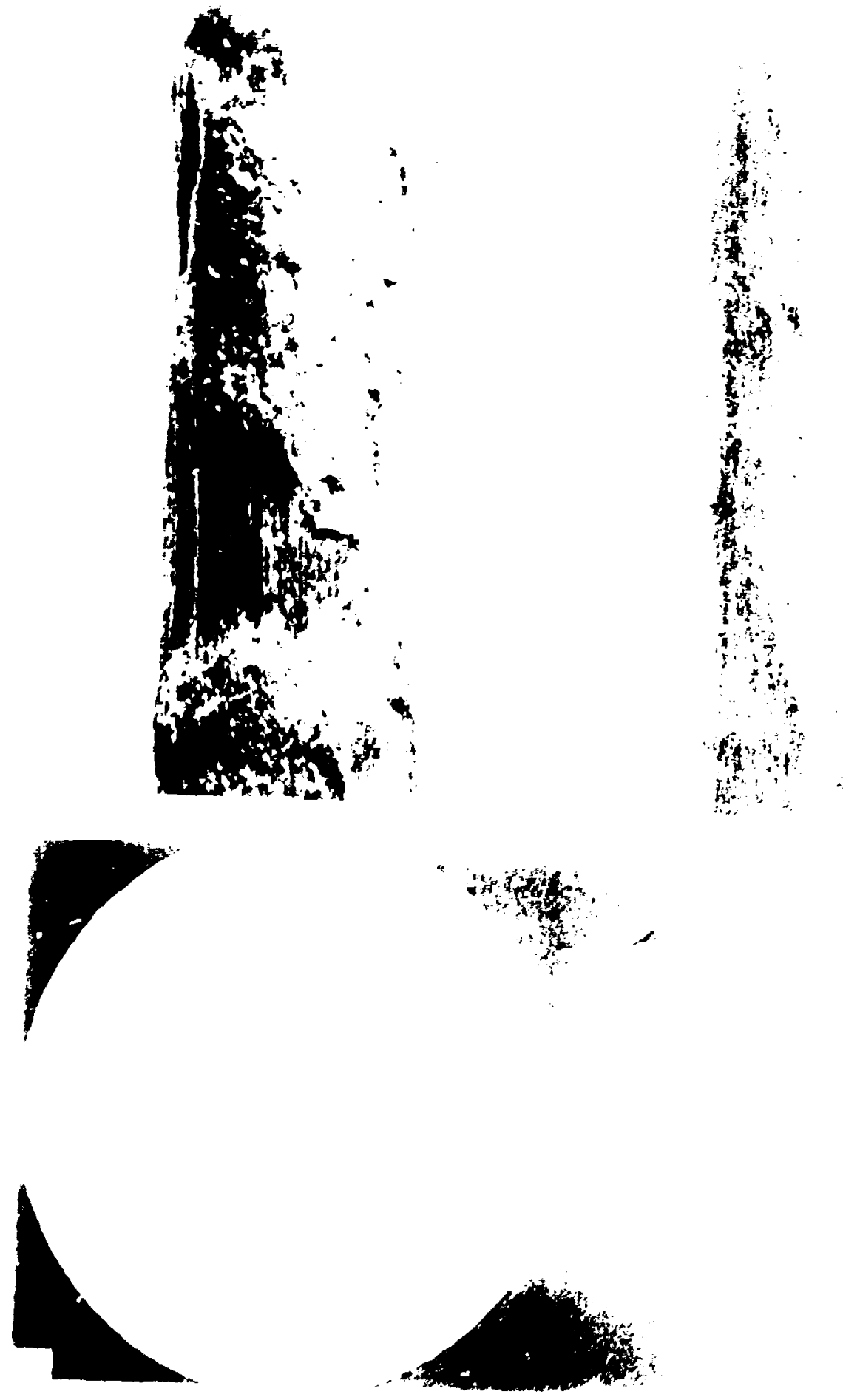
applied concrete in which the $\mathrm{pH}$ of the incorporated vater is greater than 12 should not become embrittled, even if the concrete contains appreciable concentrations of sulfide. On the other hand, it is doubtful that water in contact with greases or waxes would develop $\mathrm{pH}$ values greater than 9.5. Below this value, cracking has been observed.

The only other environments in which cracking was experienced were amonium nitrate and sodium bisulfite solutions. In both cases it is likely that cracking could have been eliminated if the pH of the solution had been increased. In the nitrate solution, temperatures also had to be above $38^{\circ} \mathrm{C}\left(100^{\circ} \mathrm{F}\right)$ to produce cracks. In the case of the sodium bisulfite solution, there was only superficial evidence of cracking, and additional testing should be conducted before any definite conclusion is drawn about the susceptibility of AISI 1080 steel to cracking in bisulfite solutions. However, sodium bisulfite would not exist in strongly alkaline solutions (sodium sulfite becomes the stable form), and in the alkaline environment, reduction to hydrogen sulfide would be unlikely. All other attempts to produce cracks in AISI 1080 steel were unsuccessful.

On the other hand, AISI 1080 steel has poor corrosion resistance to most aqueous neutral solutions and water when exposed to air, and in such environments reduction in cross-sectional area could lead to tendon failures. In tests reported here, attack was particularly severe at the waterline. Although tests were not conducted under alkaline conditions, attack would undoubtedly have been much less. In small volumes of solution with limited access to oxygen, corrosion was much less, and only a small amount of the corrosion-product hydrogen entered the steel. The amount was probably so small that it would have no ef fect on embrittlement of AISI 1080 steel. One of the reasons for using tendons made from this steel is that it is less susceptible to hydrogen embrittlement than many other more highly alloyed high-strength steels.

The corrosion of steel in concrete has been the subject of many investigations, and the ifterature Indicates that with reasonable precautions, corrosion is not a serious problem. One of the necessary precautions is to 1 imit the concentration of chloride fons to a maximum of $300 \mathrm{ppm}$ (approximately $0.01 \mathrm{M}$ ), nitrate to no more than $620 \mathrm{ppm}(0.01 \mathrm{M})$, and the sulfide (as metal sulfide) to $640 \mathrm{ppm}(0.02 \mathrm{M}$ ). These are maximum values 
recomended by Rieche $^{35}$ and are appreclably higher than those specified in U.S. Nuclear Regulatory Guide 1.107 [100 ppm Cl (200 ppm if pH > 12),

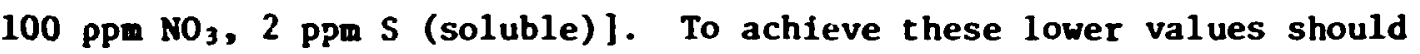
present no undue hardship or expense, and therefore it appears reasonable to take advantage of the added safety factor. Another precaution is to use minimu water in preparing the grout (water/cement ratio $=0.40$ ). This produces a grout with minimm porosity and greatly reduces carbonation, which could possibly lead to hydrogen embrittlement in extreme cases. Application of appropriate standards and procedures should result in tendon lifetimes at least equal to the design life of the vessel. The fact that many prestressed concrete vessels, bridges, and other structures are in use, many of them for many years, is proof that corrosion of prestressing steel in grouts can be reduced to an insignificant. level.

There appears to be much less experience using greases or other organic compounds in protecting tendons in prestressed structures, and therefore the prcblem of assessing the potential for corrosion is not an easy one. Generally, such organic materials provide a very protective environment so long as they remain intact and free or b...or. Even sth low levels of impurities, the greases are noncondurtors (if dry; $7_{\mathrm{i}}$ : as such should produce negligible corrostion. However, the chemical stabiltt; of these materials over very long periods of time - in a low radiation field if used in nuclear reactor containment vessels - and the nature and corrosivity of the degradation produsts are not well docimented. One apparent point is that if water is present in the grease-filled ducts containing the tendons, the $\mathrm{pH}$ of the water will not be as alkaline as the water in a grout, and, therefore, the potential for corrosion would be greater with grease than with grout.

Twn areas of tendon corrosion that have been inadequately investigated are (1) the intiation of cracks from the base of pits or in crevice regions, and (2) cracking that could occur because of galvanically coupling stressed tendons to a metal or alloy of different electrochemical activity. As noted earlier, the solutions that exist in active pits or crevices tend to be acid, and if a sulfide inclusion in the steel were exposed to such a solution, a relatively high concentration of $\mathrm{H}_{2} \mathrm{~S}$ would exist locally, possibly enough to cause fallure; or even in the absence of 
$\mathrm{H}_{2} \mathrm{~S}$ the acid enviroment may be able to produce active-path SCC as postulated by Brown. ${ }^{2}$ Ideal sites for crevice corrosion exist among the strands of tendons.

In the case of galvanic couples, two questions that have not been answered are (1) how readily are tigh-stength steel tendons embrittled by coupling to wre active metals, and (2) can coupling to wore noble netals lead to active-path SCC in an otherwise innocuous environment? The fact that tendon steels are usually cold drawn should retard activepath SCC, but probably facilitate hydrogen embrittlement.

\section{SUMEARY}

The general forms of localized corrosion were discussed, and the recent ifterature concerning the general corrosion and stress-corrosion cracking of carbon steel was reviewed. The behavior of high-strength steels used as prestressing tendons in elther concrete grouts or protective organic materials (waxes or greases) was also reviewed. Although very little information exists about corrosion of steels in the latter environment, organic substances normally produce insignificant attack on steel; there is however, a dearth of information on the long-term stability of such compounds and the corrosiveness of their degradation products. The Ifterature shows that the corrosion of high-strength steels in correctly formulated and applied cuncrete is very low, even if appreciable concentrations of chloride, nitrate, or sulfide salts are present.

Stress-corrosion cracking tests carried out with AISI 1080 steel tendon wires, using the constant-strain-rate method, produced the results expected from literature-reported information. Thus, steel wires cracked rapidly in solutions coisaining hydrogen sulfide if the pH of the solution was 7 or 1 ess but not in alkaline solutions. Cracks also forwed in $0.2 M$ ammonium nitrate but only if the temperature was above $38^{\circ} \mathrm{C}\left(100^{\circ} \mathrm{F}\right)$. Indications of cracking were als., found in a sodium bisulfite solution.

AISI 1080 steel wires cor:oded appreclably in air-saturated solutions of $0.2 \mathrm{M} \mathrm{Na}_{2} \mathrm{SO}_{4}, 0.05 \mathrm{M} \mathrm{NaCl}$, and in distilled water; attack was particularly severe at the waterline. Attack such as notel could lead to fallures due to reduction in the cross section of the load-carrying tendons. In 
sall volumes of simflar solutions that had only limfted access to air, AISI 1080 steel showed lower corrosion rates and only very small uptake of hydrogen. The severity of attack on steel tendons in the event vater pockets form around them will depend to a large measure on the availability of oxygen.

\section{ACKNOWLEDGHENTS}

It is a pleasure to acknowledge assistance from the following people in the preparation of this report: E. J. Lawrence, L. T. Ratcliff, and Steve Anderson for help in conducting the experiments; $M$. D. Allen for preparation of the metallographic specimens; Adroft for editing the report; and Kathryn $A$. Witherspoon for typing the manuscript.

\section{REFERENCES}

1. D. A. Canonico, J. C. Griess, and G. C. Robinson, Final Report on PCRV Thermal Cylinder Axial Tendon Failuass, ORNL-5110 (January 1976).

2. B. F. Brown, Ed., Stress-Corrosion Cracking in High Strength Stiels and Titanizon and AZuminum AZloys, Naval Research Laboratory, Washington, D.C., 1972, pp. 4-5.

3. M. J. Humphries and R. N. Parkins, "The Influence of Oxide Films on Stress Corrosion Cracking of Carbon Steels," pp. $384-92$ in Fundomental Aspects of Stress Composion Cracking, R. W. Staehle, Ed., National Association of Corrosion Engineers, Houston, 1969.

4. B. F. Brown, Ibid. Pp. 18-77.

5. L. L. Shrier, Corrosion, Vo1. 1, pp. 3.3-3.23, Wiley, New York, 1963.

6. H. H. Uhlig, Corrosion and Corrosion Control, 2nd. ed., Wiley, New York, 1971, pp. 93-126.

7. H. H. Uhlig, Ed., The Corrosion Handbock, Wiley, New York, 1948, pp. 124-43.

8. P. J. Hnllingum, Composion of Pre-Stressing Wires of Concrete Pressure Vessels, Tech. Report of British Engine Roiler and Electrical Insurance Co., Ltd., New Series, Vol. X, pp. 87-93 (1971). 
9. R. N. Parkins, "Stress Corıosion Cracking of Low-Strength Ferritic Steels," Pp. 167-85 in The Theory of Stress Corrosion Cracking in AZloys, J. C. Scully, Ed., MATO, Brussels, 1971.

10. J. E. Reinoehl and H. E. Berry, "Natural Conditions for Caustic Cracking of Hild Steel," Corrosion 28: 151-60 (1972).

11. H. Maztlle and H. F. Uhlig, "Effect of Temerature and Sove Inhibitors on Stress Corrosion Cracking of Carbon Steels in Nitrate and Alkaline Solutions," Corrosion 28: 427-33 (1972).

12. J. FIis, "Role of Temerature in Stress Corroston Cracking of Iron In Nitrate Soiutions," Br. Corros. J. 10: 79-84 (1975).

13. R. N. Parkins and R. "sher, "The Effect of Nitrate Solutions in Producing Stress-Corrosion Cracking in Mild Steel," pp. 289-95 in First International Congress on Metallic Corrosion, London, Apr. 10-15, 1961, Butterworths, London, 1962.

14. A. W. Loginow and E. H. Phelps, "Stress-rorrosion Cracking of Steels in Agricultural Ammonia," Corrosion 18: 299-309 (1962).

15. M. Kowaka and S. Nagata, "Transgranular Stress Corrosion Cracking of Mild Steels and Low-Alloy Steels in the $\mathrm{H}_{2} \mathrm{O}-\mathrm{CO}-\mathrm{CO}_{2}$ System," Corrosion 24: 427-29 (1968).

16. J. M. Sutcliffe, R. R. Fessler, H. K. Boyd, and R. M. Parkins, "Stress Corrosion Cracking of Carbon Steel in Carbonate Solutions," Corrosion 28: 313-20 (1972).

17. J. G. Parker and $W$, G. Pearce, "Stress Corrosion Cracking of a Low Alloy Steel in Acetate Solutions," Corrosion 30: 18-23 (1974).

18. W. R. Middleton, "Stress Corrosion Cracking of Mild Steel in a Phosphate Solution," Br. Corros. J. 8: 62-65 (1973).

19. D. Hixon and H. H. Uhlig, "Stress Corrosion Cracking of Mild Steel in Ammonfum Carbonate Solut1on," Corrosion 32: 56-59 (1976).

20. H. Buchholtz and R. Pusch, "Contribution on the Transcrystalline Stress Corrosion Cracking of Steel," Stahl Eisen 62: 21-30 (1942).

21. J. D. Gilchrist and R. Narayan, "Environmental Cracking of Eutectoid Steel," Corros. Sci. 11: 281-9ó (1971).

22. A. Asphahani and H. H. Un11g, "Stress Corrosion Cracking of 4140 High Strength Steel f.n Aqueous Solutions," J. Electrochem. Soc. 122: $174-79$ (1975). 
23. H. H. thlig, K. E. Perumal, and M. Talerman, "Stress Corroston Cracking of Iron in Nitrates: Effect of Carbon and Low Alloying Additions," Co:mesion 30: 229-31 (1974).

24. E. H. Phelps, "A Review of the Stress Corrosion Behavtor of Eceeis with High Yield Strengths," pp. $398-410$ in Fundarental Ascects of Stress Comosion Crackirc, R. W. Staehle, Ed., National Association of Corroston Eagineers, Houston, 1969.

25. J. B. Greer, "F.ictors Affecting the Sulfide Stress Cracking Performance of High Strength Steels," ilater. Perform. 14(3): 11-22 (1975).

26. NACE Committee T-IF, "Sulfide Cracking Resistant Metallic Materials for Valves for Production and Pipeline Service," iater. Prot. 5(9): $81-82$ (1966).

27. C. M. Hudgins, R. L. Glasson, P. Mehdizodeh, and W. M. Rosborough, "Hydrogen Sulfide Cracking of Carbon and Alloy Steels," Corrosion 22: 238-51 (1966).

28. A. Kawashima, K. Hashimoto, and S. Shimodaira, "Hydrogen Electrode Reartion and Hydrogen Embrittlement of Mfld Steel in Hyarogen Sulfide Solutions," Compsion 32: 321-31 (1976).

29. T. G. McCord, B. W. Bussert, P. M. Curran, and G. C. Gould, "Stress Corrosion Cracking of Steam Turbine Materfals," Hater. Perfo:m. $15(2)$ : $25-34$ (1976).

30. L. M. Dvorack, "Suifide Stress Corrosion Cracking of Steel," Coprosion 26: 177-88 (1970).

31. H. E. Townsend, Jr., "Hydrogen Sulfide Stress Corrosion Cracking of IIigh Strength Stecl Wire," Cormsion 28: 39-46 (1972).

32. R. S. Treseder and T. M. Swanen... "Fictors in Sulfide Corrosion Cracking of High Strength Steels," Coprosion 24: 31-39 (1968).

33. M. F. Baldy, "Sulfide Stress Cracking of Steels frr API Grade N-80 Tubular Products," Corrosion 17: 5n9t-13t (1961).

34. H. H. Uhlig, "Effect of Aqueous Sulfides and Their Oxidation Products on Hydrogen Cracking of Steel," Mater. Perform. 16(1): 22-25 (1977).

35. G. Rieche, "Model Experiments on Stress Corrosion in High-Strength Ster.Is in Non-Carbonated Cuncrete," Werket. Korros. 26: 19-32 (1975); ORNL-tr-4277. 
36. G. J. Verbeck, "Mechanisms of Corrosion of Steel in Concrete," pp. 21-38 in Corrosion of Metals in Concrete, Publication SP-49, American Concrete Institue, 1975.

37. R. Szilard, "Corrosion and Corrosion Protection of Tendons in Prestressed Concrete Bridges," Am. Concr. Inst. J. 66(1): 42-59 (1969).

38. D. A. Hausmann, "Steel Corrosion In Concrete," Mater. Prot. 6(11): $19-23$ (1967).

39. G. E. Honfore and G. J. Verbeck, "Corrosion of Prestressed Wire in Concrete," Am. Concr. Inst. J. 57(11): 491-515 (1960).

40. K.W.J. Treadaway, "Corrosion of Prestressed Steel Wire In Concrete," Br. Corres. J. 6: 66-72 (1971).

41. H. G. Godfrey, "Corrosion Tests on Prestressed Concrete Wire," Corrosion 17: 24-25 (1961).

42. I. Cornet, "Corrosion of Prestressed Concrete Tanks," Mater. Prot. $3(1)$ : 90-100 (1964).

43. G. N. Scott, "Corrosion Protection Properties of Portland Cement Concrete," J. Am. Water Works As8oc. 57: 1038-52 (1965).

44. N. Krishna Raju, "Corrosion of High Tensile Steel in Structural Concrete," J. Electrochem. Soc. India 22: 100-105 (1973).

45. P. Helligenstaldt and $K$. Bohnenkamp, "Investigations on the Hydrogen-Induced Brittle Fallure of Galvanized Prestressed Steels In Concrete," Arch. Eisenhuettenwes. 47: 107-12 (1976); Corros. Ab̀str. 16(2): 87 (1977).

46. S. G. Clarke, "The Use of Inhibitors (with Special Reference to Antimony) In the Selective Removal of Metallic Coatings and Rust," Trans. Electrochem. Soc. 69 : 131-44 (1936). 